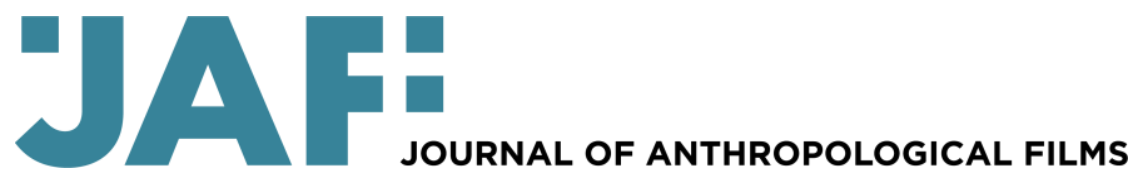

VOL 6 supplement VISCAM issue

\title{
Editorial/Éditoriale (in English and/et en Français)
}

\author{
Supplement Issue Editorial Committee: \\ Bjørn Arntsen (UiT/The Arctic University of Norway) \\ Bata Diallo \\ Len Kamerling (University of Alaska Fairbanks) \\ Babette Koultchoumi (Université de Maroua) \\ Marceline Mbetoumou (Université de Ngaoundéré) \\ Trond Waage (UiT/The Arctic University of Norway)
}

This supplement issue of JAF (Journal of Anthropological Films) invites readers to meet a variety of people living their lives in Northern Cameroon: Street children who survive on the refuse of a city, a refugee from the Central African Republic in search of an elusive stability, a woman with a college degree who brews beer in urban Ngaoundéré but dreams of landing a job as a teacher, a metalwork artisan who plays a complex role in the economic and social life of his rural community, a traditional healer who strives to preserve threatened local knowledge through his practice, a blind Boko Haram casualty who must learn to navigate both the physical and social landscape of a refugee camp, and a household of fishermen coping with huge environmental changes far beyond their control. The films published in this supplement issue are selections from the twenty-two films made by Master and $\mathrm{PhD}$ students from Cameroon, recruited and trained through the VISCAM project (Visual Anthropology at the Universities of Maroua, Ngaoundéré and UiT Arctic University of Norway) from 2017 through 2021. These films represent the work of a new generation of young visual anthropologist/filmmakers living and working in regions where the rate of illiteracy is high and films in local languages are rare.

The collaboration between UiT Arctic University of Norway and universities in Northern Cameroon began thirty years ago with the founding of the Ngaoundéré Anthropos Project, a program that recruited students from the multi-ethnic populations of the Northern region of Cameroon and that played a major role in establishing social science education in the country. The VISCAM project, an outgrowth of Ngaoundéré Anthropos, has annually hosted Cameroonian students at UiT, four of whom now hold academic positions at the University of Maroua. The goal of the VISCAM project was to develop sustainable programs in Visual Anthropology through the exchange of students and faculty and the development of innovative cross-cultural teaching and filmmaking practices that reflect the realities of modern-day Cameroon.

The development of academic institutions across cultures has its challenges. Providing the interdisciplinary learning that ethnographic filmmaking requires is a demanding task. But through the persistence of students and faculty the VISCAM project has come far in strengthening Visual Anthropology as an academic discipline in Cameroon as well as UiT. 
The films in this supplement issue of JAF take viewers into the cultural milieu of Cameroon as only Indigenous filmmakers can reveal it. We invite you to experience these films and the people they represent while celebrating a new generation of African filmmakers.

\section{The Films}

Awoudu Ways of Seeing, by Amandine Tezore, 37 minutes

Awoudu Ways of Seeing explores a theme that has become critical for our time - the toll of civilian casualties during the countless wars waged worldwide. This film is about one such casualty, Awoudu, the victim of a Boko Haram attack on his native village of Kolofata in Northern Cameroon, that took the lives of his wife and children as well as his sight. Homeless and bereft of family Awoudu lives in a refugee camp in Mayo Tsanaga, Cameroon, where he has built a makeshift shelter and learned to navigate both the physical and social landscape of his new home. The film observes Awoudu as he works to accommodate his disability, make his shelter more comfortable, and find common ground with his neighbors who are from a different ethnic group. "I became nothing," he say to the camera. "I'm starting my life over." We accompany Awoudu to the market where he sells surplus rice and to the regional hospital where he tries in vain to replace his national identification card lost after fleeing Kolofata. The growing trust and openness between filmmaker and subject is palpable as Awoudu reveals more of his history, grief, and determination to survive. Interviews with camp officials, hospital staff and neighbors provide important contextual information about the local political milieu and the rapidly changing situation of refugees. This is an intimate portrait of resilience, of a man who has lost everything but maintains a sense of optimism and hope as he adapts to his disability, his status as a refugee, and a shifting social environment. In French, Fulfulde, and Moundang with English subtitles.

\section{When a River Becomes a Border, by Robi Layio, 25 minutes}

When European colonizers came to Africa they imposed national borders to suit their spheres of influence, often with little knowledge of the region's history or of the people who lived there. In Cameroon, populations that in pre-colonial times traveled freely within their economic regions suddenly found themselves divided by arbitrary borders. When a River Becomes a Border reveals the every-day realities of families who navigate a fluid frontier between Cameroon and Chad, a culturally cohesive region split in two by an imposed national border. We learn about this reality through the experience of two young men who negotiate the frontier on a daily basis. "The border didn't exist before European colonization," says Oumar Toudjani, who guides us through this complex history. "It's the Balkanization of Africa that divided the people. It's difficult to find someone from this region who doesn't have family on the other side." Towards the end of the film, Waldiga, a university student sums up the difficult irony of their situation. "Here we can wake up in Chad and then go to bed in Cameroon". When a River Becomes a Border is skillfully shot and economically constructed. It carefully observes the comings and goings of a population split by an arbitrary national border and invites us to think more deeply about the long-term consequences of colonialism. In French, Shuwa-Arabic and Kotoko with English subtitles. 
Scrap is Our Future, by Pierre Tizi Lankissa, 35 minutes

Scrap is Our Future tells the story of Dembélé, a teenage orphan who together with other boys subsists by collecting refuse from the neighborhoods around the University in Ngaoundéré, in Nothern Cameroon, and selling it at collection sites in the city. Dembéle and his friends search the streets and garbage dumps for "treasures", such as worn-out shoes and old shirts. The local citizens are often hostile. They store their found scrap in the backyard of an abandoned house. This is where they eat and consume the drugs they buy with their meager profits - glue, Tramadol (a powerful opiate), cocaine, hashish and alcohol. We learn about Dembéle 's hopes and dreams which are eclipsed by hunger, poverty and the haze of drugs. Towards the end of the film we follow the boys into the city where they sell their scrap in a tense exchange with exploitative middlemen. In the city, Dembélé visits his aunt. High on drugs he promises her that he will stop using and pull his life together. The film gives viewers a strong sense of observational presence. It stays close to Dembéle but always feels respectful as it follows the continuity of his days spent subsisting on the streets of Ngaoundéré. The film poses important questions about the growing migration of rural people to the urban areas of Cameroon and the economic challenges they face, the lack of care and assistance for homeless children and the ubiquitous presence of drugs in areas struggling with poverty. In French and Fulfulde with English subtitles.

\section{Daily Survival, by Abdoul Aziz Wadazoua, 39 minutes}

In the village of Mandjour, on the banks of the River Logone in the extreme North of Cameroon, Moumin heads a fishing household of forty-seven people. Because of ecological degradations, fishing alone can no longer secure the family's survival and must be complimented with the cultivation of rice and cattle breeding. The film observes the household's subsistence activities when the annual flooding of the plains transforms farmland and pastures into fishing grounds. It provides insightful evidence into how these different activities both complement and challenge subsistence by demanding traditional knowledge as well as the acquisition of new technical skills. Although the fishermen of Mandjour are at the mercy of global ecological forces, they are adapting in ways that further transform the local environment. For example, digging deep channels that allow fishermen to capture large quantities of juveniles departing from the spawning areas, an activity that could have major consequences on the future survival of fish stocks. Daily Survival is a film with a strong sense of "being-there-ness" that creates a sensorial experience of life in Mandjour. Moumin openly shares his life with the filmmaker and the rapport between them is one of the main strengths of the film. The topics presented will contribute much to discussions on ecological transformations and cultural coping strategies. In Mousgoum and Fulfulde with French subtitles.

\section{We Are together, by Ascanio Varroni, 33 minutes}

The city of Ngaoudéré in Northern Cameroon has a steady stream of migrants arriving from neighboring regions. Jean Louis is a refugee from the Central African Republic living in Ngaoudéré in search of stability and a better life for his family. Ascanio Varroni is a graduate student in visual anthropology. He came to Cameroon to make a film about the every-day realities that migrants and refugees face in a new country. There he met Jean 
Louis and a friendship formed. We Are Together deals with the difficulties of social integration for migrants in host communities and the long-term consequences of poverty and alienation. But it is also about the relationship between filmmaker/anthropologist and subject, the cultural expectations, misinterpretations, and challenges of maintaining a friendship across economic and cultural boundaries. The film reveals how Jean Louis' expectations conflict with the filmmaker's and how difficult it is to disentangle the filmin-progress from this misunderstanding. This is a situation that many who have done social science fieldwork will recognize. In classic observational style the film follows Jean Louis as he applies his masonry skills to earn money and to win the favor of a local "patron" who can provide both employment and social status. Interviews with the patron and other residents sheds light on the broader situation of migrants, how they are supported, exploited, and the long path they must travel for acceptance and stability. In French, English, Kaba, and Fulfulde with English subtitles.

\section{I, a Ngwazla, by Wouleo Kazla Elie, 29 minutes}

I, a Ngwazla, explores the layers of experience and obligation that make up the lives of artisan metalworkers in Mafa society. We learn about this through Zayadai, a metalworker trained by his father with the expectation that he will carry on the trade. Unlike many of his contemporaries, Zayadai had the opportunity to attend school, but quit after his father's death to take up the trade passed down to him and become a Ngwazla. Helped by his three younger brothers, Zayadai practices his craft to meet the needs of his community, the Mafa village of Djinglia Kongoche in the North of Cameroon, an agricultural area that depends on the local manufacture of strong, dependable metal farming tools. Through his trade Zayadai also supports his wife, his mother and eleven brothers. In traditional Mafa society the Ngwazla functions as craftsman, healer, diviner, and gravedigger. These functions place the Ngwazla in an ambiguous situation as he is both respected and feared. Zayaida insists that he is only a metalworker and strictly refrains from performing the marginalizing tasks of the traditional Ngwazla, such as digging graves and carrying the corpse in funeral ceremonies. His work corresponds to the seasons, climate and environment which gives him independence but also makes him vulnerable to unexpected change. I, a Ngwazla, is a perceptive and closely observed portrait of a Mafa artesian that reveals the economic and cultural links between agricultural subsistence, the craft of making metal tools, and the status of the Ngwazla in his community. In French and Mafa with French subtitles.

\section{Djebba's Caberet, by Ghislaine Magouo Tainon, 30 minutes}

Djebba's Cabaret tells the story of Djebba, an energetic young woman who has trained as a teacher but has been unable to find work. To support herself in the city of Ngaoundéré, Cameroon, she brews and sells "bil bil", a traditional millet beer. She hopes one day to get a good paying job in education or in public service administration. In the meantime, she has opened a business - a small bil bil pub - that allows her to make ends meet. Young people in Cameroon seem to have more faith in finding opportunities from the public sector than private business, which feels uncertain and precarious. It is the culture of "waiting" for opportunity and finding some kind of employment to get by. Despite the low profits of the brewing business, Djebba has won the loyalty of a large number of customers with whom she shares warm and familiar relationships. She has succeeded in turning her cabaret into a relaxed and comfortable cultural space, not only for the 
consumption of bil bil but to support a circle of local organizations and friends. Djebba's brewing business allows her to live and survive economically, but she still hopes to fulfill her dream and put her education to work as a teacher or administrator. In classic observational style, Djebba's Caberet highlights a culture of economic survival inhabited by young people in search of stability, in a rapidly changing society without fixed points of reference. In French, Fulfulde and Moundang with English subtitles.

Yiga Kaka, by Aboubakar Hamadama , 25 minutes

In the village of $\mathrm{Ngan} \mathrm{Ha}$ in Northern Cameroon, a traditional healer prepares for his daily practice. He chooses his medicinal plants and gets ready to receive patients. "I do cockerel diagnosis whenever I doubt the source of a patient's illness", the healer tells us. This requires eviscerating a cockerel and closely examining the inner parts. What the healer sees in the physical manifestation of the animal, informed by the gods, instructs his diagnosis. The film observes these procedures as the healer treats several local woman, a man suffering from impotence and as he dispenses medicinal herbs in his clinic. A local medical doctor at the regional hospital explains that he has been working with traditional healers since 2017. "Now during the Covid-19 pandemic it is particularly important to maintain partnerships between science and tradition", he tells us. "When they find illness that they don't understand, they come to us". In the traditional clinic, patients are masked and seated widely apart. "Let's respect Covid-19 social distancing," the healer says to a group of patients as they wait to be treated. This is a spiritual healing practice where disease diagnosis is more cultural than physical and where the causes are rooted in strong beliefs and the channeling of divine intervention. The mystical-religious dimension of healing is at the center of this observational film. In Mboum with English subtitles.

\section{Married at 13 Years, 13 Years ago, by Mostapha Bako, 32 minutes}

Married at 13 Years focuses on the forced marriage of young girls in the North of Cameroon. It is an observational portrait of a young woman compelled into an early marriage at the age of thirteen who eventually escapes from her precarious situation. After extricating herself from an abusive marriage, she works as an escort in order to get by financially and support her mother and young children. But she dreams about a future in music entertainment. Confident in her own abilities and ambitious for success, she explores every path to her chosen career.

The film begins with an account of how the men in her family forced her into an unwanted marriage. It gives a strong sense of her struggle to survive economically and the emotional toll it took. The film follows her daily life, first as an escort preparing to meet clients, as a homemaker and mother, and finally discovering opportunities to pursue a career as a music entertainer. The film tracks her growing development and independence, her courage and her determination to succeeded. Married at 13 Years is well constructed and shot. It is an unambiguous portrait of a young woman's struggle for self-determination, but it is also a mirror of the broader cultural problems of forced marriage, diminished women's rights and the lack of assistance for women escaping abusive marriages. In Fulfulde with English subtitles. 
Change of Perspectives, by Ldouma Rebecca, 24 minutes

The Oumarou family lived a nomadic way of life before settling on the outskirts of Ngaoundéré, in northern Cameroon. Change of Perspective observes how the family adapts to their new life by focusing on the activities of the wife, Hadjara, as she makes inroads to her new community and learns about health care options previously unavailable to nomadic people. The film takes us through Hadjara's pregnancy, prenatal examinations and finally, the emotional delivery of her new child at the private Protestant Health Center of Dang. This film is also about the transformation taking place in the practice of traditional midwifery in the region. Introduction of "Le Chèque de Santé", a health insurance voucher system of the Far North region of Cameroon helps insure affordable quality care for local families. An interview with Amina, a former traditional midwife, recounts what childbirth was like for nomadic people in former times. "There was nothing left", she says. "The hospital took everything". The film illustrates the cultural manifestations of lives balanced between tradition and modernity as families make critical healthcare decisions. The tension between the two is palpable both from health workers and patients. The growing awareness of local women about opportunities brought by change have led many to trade the tradition of home birth for safer deliveries in medical health centers where both prenatal and postnatal care are available. In Fulfulde with French subtitles.

\section{Éditorial - JAF Numéro Spécial}

Le présent numéro spécial du JAF (Journal of Anthropological Films) présente une variété de travaux issus de l'expérience de différents chercheurs d'avec le terrain au Nord-Cameroun. Les thématiques développées dans ces travaux sont variées et concernent entre autres : la problématique des enfants de la rue vivant en bordure de route; des réfugiés de la République Centrafricaine à la recherche d'une stabilité relative; des femmes brassant de la bière traditionnelle dans la ville de Ngaoundéré et aspirant à une meilleure condition socioprofessionnelle ; des artisans métallurgistes assumant un rôle complexe sur l'échiquier socio-économique local ; du guérisseur traditionnel s'efforçant à préserver des pratiques ancestrales en proie aux défis de la modernité ; d'une victime aveugle de Boko Haram cherchant à s'adapter au paysage physique et social d'un camp de réfugiés ; et d'une famille de pêcheurs faisant face à de profondes mutations environnementales incontrôlables. Les documentaires présentés dans ce numéro spécial sont issus des vingt-deux films réalisés par des étudiants de Master et de Doctorat/Ph.D du Cameroun, recrutés et formés dans le cadre du projet VISCAM (Anthropologie visuelle à l'Université de Maroua, de Ngaoundéré et à l'UIT-l'Université Arctique de Norvège à Tromsø) de 2017 à 2021. Ces courts métrages représentent en effet le travail d'une nouvelle génération de jeunes anthropologues visuels/cinéastes vivant et travaillant dans des régions où le taux d'analphabétisme reste élevé, et où les films en langues locales sont très rares.

La collaboration entre l'UIT et les Universités du Nord- Cameroun a débuté il y a trente ans, avec la création du projet Ngaoundéré Anthropos. En effet, le programme recrutait des étudiants parmi les populations d'ethnies et de religions différentes vivant dans la région du Nord-Cameroun. Il a ainsi contribué à mettre en place et à valoriser 
l'enseignement et la recherche en sciences sociales dans cette partie du pays. Le projet VISCAM, une excroissance du projet Ngaoundéré Anthropos, a accueilli chaque année des étudiants camerounais à l'UiT, dont quatre occupent maintenant des postes académiques à l'Université de Maroua. L'objectif dudit projet était en effet de développer des programmes durables en anthropologie visuelle, grâce à l'échange d'étudiants et d'enseignants, en introduisant un enseignement interculturel innovant et des pratiques cinématographiques qui reflètent les réalités du Cameroun d'aujourd'hui.

Le développement d'institutions universitaires transculturelles n'est pas sans défis. Offrir l'apprentissage interdisciplinaire que requiert la réalisation des films ethnographiques est une tâche exigeante. Mais, grâce à la persévérance des étudiants et du corps enseignant, le projet VISCAM a permis de renforcer l'anthropologie visuelle en tant que discipline universitaire au Cameroun et à l'UIT.

Les films de ce numéro spécial du JAF plongent les spectateurs dans le milieu socioculturel camerounais que seuls les cinéastes locaux peuvent reproduire. Il incite ainsi le spectateur à découvrir ces films et les personnes qu'ils présentent tout en célébrant cette nouvelle génération de cinéastes africains.

\section{Les Films}

Awoudu Ways of Seeing, par Amandine Tezore, 37 minutes

Le film Awoudu Ways of Seeing, aborde une thématique intéressante, celle de la résilience d'une victime de Boko Haram, recueillie dans un camp de réfugié à Mayo Tsanaga, Cameroun. Il a tout perdu : son village, sa famille et même un organe vital (la vue). C'est un documentaire qui contribue à la construction du savoir anthropologique en termes de pratiques, de comportements et de perceptions. Pour ce faire, le film traite ainsi des questions des sociétés africaines : la guerre et ses victimes, les traumatismes physiques, psychologiques, la réinsertion des victimes, la reconstruction de la vie des migrants, etc. Ce court métrage dresse ainsi le portrait et le quotidien d'un homme qui réapprend à vivre avec son handicap. Le réalisateur présente le personnage dans plusieurs lieux: son habitation, l'hôpital ; le marché ; le forage, le voisinage et l'interroge sur la pratique de ses activités ainsi que ses relations avec son environnement immédiat. Les séquences les plus longues de son œuvre sont notamment celles sur l'espace d'habitation et sur le forage qui mettent en exergue la résilience du personnage face à son nouveau statut social de handicapé. La perspective des images (gros plans, plans rapprochés) est bonne parce qu'elle permet de mettre en relief les émotions des personnages impliqués. Les entretiens, dignes d'intérêt, quant à eux offrent des informations contextuelles, bien qu'ils soient parfois longs, s'assimilant de ce fait à un reportage. Le film est en français, fulfulde, et moundang avec sous-titrage en anglais.

\section{Quand la rivière devient une frontière, par Robi Layio, 25 minutes}

Lorsque les colonisateurs européens sont arrivés en Afrique, ils ont imposé des frontières nationales en fonction de leurs sphères d'influence, souvent avec une faible connaissance de l'histoire de la région ou des personnes qui y vivent. Au Cameroun, des populations qui, à l'époque précoloniale, se déplaçaient librement au sein de leurs zones de confort économique se sont soudainement retrouvées divisées par des frontières arbitraires. Quand la rivière devient une frontière, expose les réalités quotidiennes de ces familles et des individus 
naviguant sur une frontière fluide entre le Cameroun et le Tchad, une région culturellement homogène, coupée en deux par une frontière nationale imposée. Nous découvrons cette réalité à travers l'expérience de deux jeunes hommes qui négocient quotidiennement la frontière. "La frontière n'existait pas avant la colonisation européenne", explique Oumar Toudjani, qui nous guide à travers cette histoire complexe. "C'est la balkanisation de l'Afrique qui a divisé les individus. Il est difficile de trouver une personne de cette région qui n'a pas de famille de l'autre côté de la rive." Vers la fin du film, Waldiga, un étudiant résume l'ironie de leur situation quotidienne en ces termes : «Ici, on peut se réveiller au Tchad et se coucher au Cameroun ». Quand la rivière devient une frontière, est un court métrage bien réalisé et synthétisé. Il permet de scruter, de manière attentive, les allées et venues des personnes traversant la frontière du lac Tchad et pousse à réfléchir profondément aux conséquences de la colonisation à long terme. Le film est en français, shuwa-arabe, et kotoko avec sous-titrage en anglais.

\section{La ferraille est notre avenit, par Pierre Tizi Lankissa, 35 minutes}

La ferraille est notre avenir, narre l'histoire de Dembélé, un adolescent orphelin qui, pour subvenir à ses besoins, ramasse et vend, avec ses compagnons, des déchets dans les quartiers bordant l'Université de Ngaoundéré, dans la région de l'Adamaoua au NordCameroun. Dembélé et ses amis fouillent les rues et les décharges à la recherche des "trésors" tels que : des chaussures usées, de vieilles chemises, des boîtes de conserve et de la ferraille. Les habitants des quartiers où errent l'adolescent et ses compagnons leur sont souvent hostiles. Le butin qu'ils amassent est stocké dans la cour abandonnée d'une maison en ruine en attendant leur exportation vers la ville, point de leur livraison. C'est dans cette cour insalubre qu'ils mangent et consomment des drogues qu'ils achètent avec leur gain journalier - colle, Tramadol (un opiacé puissant), cocaïne, haschisch et alcool. Le spectateur découvre ainsi les espoirs et les rêves de Dembélé, déchus par la faim, la pauvreté et les effets de la drogue. Le film expose également le circuit de livraison, de vente et de recyclage des déchets de la cité universitaire de Ngaoundéré où se mêlent à la fois escroquerie, exploitation et transaction frauduleuse de tout genre. La ferraille est notre avenir, donne au spectateur un fort sentiment de présence observatrice. La caméra, toujours proche de Dembélé, se montre cependant respectueuse de son intimité. Le film soulève ainsi des questions importantes liées à la problématique de l'exode rural, aux défis économiques auxquels les jeunes exilés sont confrontés, aux manques de soins et d'assistance pour les enfants sans abris et à l'omniprésence de la drogue dans ces milieux pauvres en proie à la délinquance. Le film est en français et fulfulde avec sous-titrage en anglais.

\section{Survivre au quotidien, par Abdoul Aziz Wadazoua, 39 minutes}

Dans le village de Mandjour, sur les rives du fleuve Logone, à l'Extrême-Nord du Cameroun, Moumin est à la tête d'une famille de pêcheurs de quarante-sept personnes. En raison des dégradations écologiques, la pêche seule ne peut assurer la survie de la famille. Elle doit être secondée par la culture du riz et l'élevage du bétail. Le réalisateur, AbdoulAziz Wadazoua, observe les activités de subsistance de ce ménage lorsque l'inondation annuelle des plaines du Logone transforme les terres agricoles et les pâturages en lieux de pêche. Le film donne un aperçu de la manière dont ces différentes activités se complètent et se défient mutuellement, en exigeant la préservation des connaissances traditionnelles et l'acquisition de nouvelles compétences. La population de Mandjour est, en quelque sorte, à la merci des changements écologiques mondiaux. Mais, elle a la possibilité de s'adapter 
aux forces globales et, de manière spécifique, de transformer son environnement local. En creusant par exemple des canaux profonds qui permettent aux pêcheurs de capturer de grandes quantités de juvéniles quittant les zones de ponte, cette pratique pourrait avoir des fâcheuses conséquences futures en rapport avec la survie des stocks de poissons. Abdoul Aziz Wadazoua a réalisé ce film avec un fort sentiment « d'être présent » qui reproduit une expérience sensorielle de la vie à Mandjour. Moumin partage ouvertement sa vie avec le cinéaste. La relation entre les deux hommes est ainsi l'une des principales forces du film. Wadazoua utilise le langage cinématographique avec assurance, en combinant observations filmées et entretiens dialogués. Le travail de la caméra est de qualité, la narration créée est claire et le sujet novateur en ce sens qu'il contribue aux débats en sciences sociales sur les transformations écologiques et les stratégies d'adaptation. Le film est en mousgoum et fulfulde avec sous-titrage en français.

\section{Nous sommes ensemble, par Ascanio Varroni, 33 minutes}

La ville de Ngaoudéré, située au nord du Cameroun, reçoit un flux constant de migrants en provenance des régions voisines. Nous sommes ensemble, aborde le problème de l'insertion sociale des migrants dans leur pays d'accueil (travail, logement, etc.). L'auteur de ce documentaire, Ascanio Varroni, explore le quotidien d'un migrant, Jean Louis, et met en relief ses stratégies d'adaptation grâce à ses compétences et son savoir-faire en maçonnerie. Le film soulève ainsi des questions existentielles liées à l'humanisme des peuples : l'accueil, l'hospitalité, les abus, la pauvreté, la vulnérabilité, les conditions difficiles de travail, la rémunération, etc. Pour s'introduire dans le quotidien de ce migrant, l'anthropologue cinéaste opte pour une approche observationnelle afin de mener sa recherche. Pour ce faire, il utilise de prime abord un appareil photo pour sa prise de contact, mais aussi pour faciliter l'entrée de la caméra et avoir des affinités avec son personnage principal. Il partage les images collectées avec ses informateurs. Elles permettent également de saisir les difficultés à opérationnaliser sa recherche avec l'outil visuel, dans un domaine tel que celui de l'émigration. En outre, les séquences sur les activités, l'environnement social du personnage mettent en exergue ses actions et ses interactions en contexte, tout en présentant le cadre de travail et du lieu d'habitation, les gestes, les expressions faciales et le ton des personnages qui concourent à la construction d'un cadre sémiotique global. Les entretiens réalisés éclairent ainsi le spectateur sur le conflit, les abus, la rémunération dérisoire dont sont victimes les émigrés en pays d'accueil. Somme toute, l'enquête ethnographique Nous sommes ensemble de Ascanio Varroni est d'une contribution euristique et méthodologique importante en ce sens qu'elle s'intéresse à un phénomène social actuel et qu'elle permet de questionner l'approche observationnelle basée sur la rémunération de l'informateur. Le film est en français, anglais, kaba, et fulfulde avec sous-titrage en anglais.

\section{Moi, un Ngwazla, par Elie Wouléo, 29 minutes}

Moi, un Ngwazla, de Elie Wouléo traite de la question des identités multiples chez les forgerons mafa de l'Extrême-Nord Cameroun. En effet, le statut des forgerons dans cette communauté a toujours été apprécié à l'aune de celui des non-forgerons. Dans ce documentaire, le cinéaste essaie de mettre en scène la perception et les représentations qu'ont les forgerons d'eux-mêmes et de leur statut. Il ressort de ce fait que ces forgerons ont des trajectoires distinctes qui les discriminent, voire les hiérarchisent. Le personnage principal du film, fier de son métier, se dit satisfait de ne faire que de la poterie et de la forge. Pareille pour sa mère et son épouse, respectivement guérisseuse et potière. Les 
activités des forgerons décrites dans le film correspondent et s'adaptent aux saisons, au climat et au relief. Ce qui les rend tantôt dépendants, tantôt vulnérables, mais surtout maîtres de leur environnement physique et de leur cosmogonie. Ce qui, par conséquent, détermine à la fois leur fragilité et leur force, mais entretient aussi, paradoxalement, leur proximité et leur distance d'avec le reste de la communauté. En effet, le discours sur les forgerons en pays mafa révèle un dénigrement et une double marginalisation de cette caste de fossoyeurs, assimilées à de la saleté et de l'impureté. L'on peut manger et boire avec des forgerons " propres », mais pas épouser leurs femmes. Tout porte à croire que les principes matrimoniaux dans cette communauté sont encore très rigides et sujets à des controverses sociales. La qualité ethnographique du film d'Eli Wouléo réside également dans les jeux de rôles qui mettent en exergue les contradictions sociologiques des identités manipulées et instrumentalisées à des fins existentiels plus «nobles ». Les forgerons projettent ainsi au quotidien, sur eux, le regard stéréotypé et stigmatisant des non-forgerons et du reste de la société à leurs égards. Le film est en français et mafa avec sous-titrage en français.

\section{Le cabaret de Djebba, par Gislaine M. Tainon, 30 minutes}

Le cabaret de Djebba, est la biographie d'une entrepreneuse locale, Djebba, femme diplômée au chômage, vendeuse de bière traditionnelle appelée bil bil, dans la ville de Ngaoundéré, Cameroun. Dans l'espoir d'entrer dans la fonction publique, elle ouvre un business qui lui permet de survivre. Cette pratique, courante dans l'environnement social camerounais, rappelle le sort et l'aspiration de plusieurs jeunes, plus intéressés par la fonction publique que le secteur privé jugé incertain et précaire. Par le choix conjoncturel qu'elle opère, Djebba, par le bai des relations construites autour de son cabaret, réussit à faire de cet espace physique, un cadre psychosocial où ses «clients » se soutiennent mutuellement et, à tour de rôle, transforment la consommation du bil bil en un cercle d'écoute et de veille fraternelle et conviviale. Le cabaret réunit également un ensemble de jeunes organisés en association et en groupe d'entraide financière dont le socle est basé sur la confiance mutuelle. Le film de Gislaine M.Tainon qui projette tous ces faits a donc une portée anthropologique en ce sens qu'il met en relief une culture de survivance développée par une jeunesse sans repère. Le film est en français, fulfulde, et moundang avec sous-titrage en anglais.

\section{Yiga Kaka, par Hamadama Abubakar, 25 minutes}

Dans le village de Ngan Ha au Cameroun, un guérisseur traditionnel se prépare pour son travail quotidien. La vie d'un coq contre celle d'une jeune femme. C'est ce que l'acte de «Yika Kaka» traduit en image au début du film. Le cinéaste met en exergue la rencontre des dieux (représentés par des touffes d'herbes et des plantes dans la cour du tradipraticien) et des humains à travers les usages des différentes plantes, de l'eau et des animaux spécifiques pour diagnostiquer, soigner et guérir les malades. Le film « Yiga Kaka» de Hamadama Abubakar nous plonge dans le domaine de l'anthropologie médicale africaine où la maladie, davantage métaphysique que physique, provient des facteurs enracinés dans les croyances locales tels que : les sorts jetés et les malédictions, la sorcellerie et autres pratiques occultes. La dimension mystico-religieuse est donc au centre de la trame narrative, avec en clé, les rapports de l'homme à son environnement et à son cosmos. La portée ethnographique de « Yiga Kaka » demeure dans sa mise en scène du quotidien des praticiens de la médecine traditionnelle à Ngan Ha. Il expose ainsi les typologies de maladies propres aux hommes et aux femmes, lesquelles maladies sont traitées en tenant 
compte des spécificités liées à chaque genre, par des approches thérapeutiques différenciées. Le film est en mboum avec sous-titrage en anglais.

Mariée à 13 ans, il y’a 13ans, par Mostapha Bako, 32 minutes

Marié à 13 ans, est un film sur le mariage forcé des jeunes filles dans le Septentrion Cameroun. Il dresse le portrait d'une jeune femme ayant vécu le mariage précoce. Le film débute ainsi par un récit sur la manière dont elle a été envoyée en mariage par les hommes de sa famille. Puis, il expose ensuite sa vie après ce mariage forcé. L'anthropologue cinéaste suit l'héroïne de ce court-métrage dans son quotidien, en présentant les différentes activités dans lesquelles elle s'investit pour s'épanouir, et surtout, pour subvenir aux besoins de sa mère et de ses enfants. Ce film met en exergue des questions liées à la personnalité de la jeune femme: son courage, sa liberté, son ambition, son intelligence, sa bravoure, sa vaillance, sa niaque de réussir, sa maturité et sa prise de conscience. Les séquences sur les activités, l'environnement social du personnage montrent comment le mariage forcé qu'elle a vécu a forgé sa personnalité. Les séquences les plus denses sont en outre celles sur sa mise en beauté, sur les activités de divertissement (danse et cours de chant, etc.) qui permettent de réaliser des gros plans sur les gestes, les expressions faciales, le ton afin de déterminer leur portée sémiotique. Le film est en fulfulde avec sous-titrage anglais.

\section{Changement de Perspective, par Ldouma Rebecca, 24 minutes}

La famille Oumarou a vécu un mode de vie nomade avant de s'installer dans la banlieue de Ngaoundéré, au Nord-Cameroun. Changement de Perspective, montre comment cette famille s'adapte à sa nouvelle vie en se focalisant principalement sur les activités de l'épouse, Hadjara, alors qu'elle s'insère dans sa nouvelle communauté et opte pour des soins de santé auparavant inaccessibles aux nomades. Le film nous fait vivre la grossesse de Hadjara, les examens prénataux et l'accouchement émouvant de son nouvel enfant, au Centre de Santé Protestant Privé de Dang. Il traite également des mutations qui s'opèrent dans la pratique du métier de sages-femmes traditionnelles dans la région. Le "Chèque Santé", un système de bons d'assurance maladie dans les régions du Nord-Cameroun qui permet d'assurer des soins de qualité à un prix préférentiel pour les familles locales, est donc au centre des différentes thématiques abordées par le film. Une interview d'Amina, ancienne sage-femme traditionnelle, raconte ce qu'était l'accouchement pour les populations nomades d'autrefois. "Il n'y a plus rien", dit-elle. "L'hôpital a tout pris". Le film illustre les manifestations culturelles des vies équilibrées entre tradition et modernité, alors que les familles prennent des décisions cruciales en matière de soins de santé. La tension entre les deux est palpable, tant chez les agents de santé que chez les patients. La sensibilisation croissante des femmes locales aux possibilités offertes par le changement a conduit nombre d'entre elles à abandonner la tradition des accouchements à domicile au profit d'accouchements plus sûrs dans des centres de santé où des soins prénataux et postnataux sont accessibles à moindre coût. Le film est en fulfulde avec sous-titrage en français. 